\title{
Galls of Cecidoses eremita Curtis and Eucecidoses minutanus Brèthes (Lepidoptera: Cecidosidae) in Magdalena, Buenos Aires Province: preliminary study and associated fauna
}

\author{
Veronica Loetti ${ }^{1}$, Alejandra Valverde ${ }^{2}$ \& Diana Nora Rubel ${ }^{1 *}$ \\ ${ }^{1}$ Universidad de Buenos Aires, Facultad de Ciencias Exactas y Naturales, Departamento de Ecología, \\ Genética y Evolución, Ciudad Autónoma de Buenos Aires, Buenos Aires, Argentina. \\ ${ }^{2}$ Universidad de Buenos Aires, Facultad de Ciencias Exactas y Naturales, Departamento de Biodiversidad y Biología \\ Experimental, Ciudad Autónoma de Buenos Aires, Buenos Aires, Argentina. \\ *Corresponding author: Diana Nora Rubel, e-mail: dianaru@ege.fcen.uba.ar
}

LOETTI, V., VALVERDE, A., RUBEL, D.N. Galls of Cecidoses eremita Curtis and Eucecidoses minutanus Brèthes (Lepidoptera: Cecidosidae) in Magdalena, Buenos Aires Province: preliminary study and associated fauna. Biota Neotropica. 16(4): e20160161. http://dx.doi.org/10.1590/1676-0611-BN-2016-0161

\begin{abstract}
In Argentina, five galling species of the family Cecidosidae (Lepidoptera), including Cecidoses eremita Curtis and Eucecidoses minutanus Brèthes, have been cited. This note reports a preliminary study of their galls in "molles" (Schinus longifolius (Lindl.) Speg.) of Magdalena (Buenos Aires, Argentina). In April 2013, galls of C. eremita and E. minutanus were censused in randomly selected "molles". In April and December 2013, randomly selected galls were then collected and transported to our laboratory in hermetic bags, and conserved at $-18{ }^{\circ} \mathrm{C}$ until examination. Maximum diameter and wall thickness of collected galls were measured. About $84 \%$ of the observed "molles" (103/123) had galls of C. eremita and/or E. minutanus. The median of galls per tree was $12(\mathrm{Q} 1=6 ; \mathrm{Q} 3=22)$. Eucecidoses minutanus had galls with smaller diameter $\left(\mathrm{U}_{11 ; 53}=583 ; \mathrm{P}<0.05\right)$ and thinner wall $\left(\mathrm{U}_{10 ; 52}=506.5 ; \mathrm{P}<0 . .05\right)$ than $C$. eremita. In open galls, we found Pseudoescorpionida, Araneae (Segestriidae and Salticidae), and larvae of Lepidoptera and Hymenoptera. Within closed galls, we found adults of Torymidae and Chalcidoidea, and larvae of Ichneumonoidea.
\end{abstract}

Keywords: Schinus longifolius, native forest, parasitoid, Ichneumonoidea, Torymidae.

\section{Agallas de Cecidoses eremita Curtis y Eucecidoses minutanus Brèthes (Lepidoptera: Cecidosidae) en Magdalena, Prov. de Buenos Aires: muestreo preliminar y fauna asociada}

\begin{abstract}
Resumen: En Argentina se registran cinco especies cecidógenas de la familia Cecidosidae (Lepidoptera), entre ellas Cecidoses eremita Curtis y Eucecidoses minutanus Brèthes. Se reporta un estudio preliminar de agallas de estas dos especies en "molles" (Schinus longifolius (Lindl.) Speg.) de Magdalena (Buenos Aires). En abril de 2013 se censaron las agallas de C. eremita y E. minutanus en molles seleccionados al azar. En abril y diciembre de 2013, se colectaron mediante muestreo aleatorio agallas de ambas especies, se trasladaron en bolsas herméticas y se conservaron a $-18^{\circ} \mathrm{C}$ hasta ser examinadas. Se midieron el diámetro máximo y el grosor de la pared. Un 84\% de los molles observados (103/123) presentaron agallas de C. eremita y/o E. minutanus. La mediana de agallas cerradas por árbol fue $12(\mathrm{Q} 1=6$ y Q3=22). Las agallas de $E$. minutanus presentaron un diámetro menor $\left(\mathrm{U}_{11 ; 53}=583 ; \mathrm{P}<0,05\right)$ y una pared más delgada $\left(\mathrm{U}_{10 ; 52}=506,5\right.$; $\mathrm{P}<0,05)$ que las de C. eremita. Los organismos asociados a las agallas abiertas fueron Pseudoescorpionida, Araneae (Segestriidae y Salticidae), y larvas de Lepidoptera y de Hymenoptera. Dentro de las agallas cerradas se encontraron adultos de Torymidae y de Chalcidoidea, y larvas de Ichneumonoidea.
\end{abstract}

Palabras clave: Schinus longifolius, bosque nativo, parasitoide, Ichneumonoidea, Torymidae.

\section{Introduction}

Gall formation in plant tissues is induced by galling organisms, mainly insects. The response to the stimulus from gall-making insects is the development of a specific morphological structure originated by hypertrophy (abnormal growth) and hyperplasia (increase in cell size). This structure or gall provides food and shelter for the gall-inducing organism (Nieves-Aldrey 1998, Stone \& Schönrogge 2003, Albert et al. 2011, Dias et al. 2013). Galls also show associated fauna of parasitoids and inquiline species (Pujade-Villar \& Ros-Farré 1998, Askew et al. 2013, Kuzmanich et al. 2015).

In South America, most studies have been carried out in Brazil. In Argentina, the first lists of gall-inducing organisms and their associated fauna were published in 1916 and 1917 by Brèthes and Jörgensen respectively. These first lists named five gall-inducing species of the family Cecidosidae (Incurvarioidea, Lepidoptera) in trees of the genus Schinus Linneo (Anacardiaceae): Cecidoses eremita Curtis, Eucecidoses 
minutanus Brèthes, Dicranoses congregatella Brèthes, Dicranoses capsulifex Kieffer and Jörgensen and Oliera argentiniana Brèthes.

The galls of C. eremita and E. minutanus, named "matecitos" or "tabaneras" by inhabitants of Buenos Aires Province, are globose stem galls and smooth surface and glabrous. The colour is firstly green and brown later. They have a single spherical larval chamber, and an operculum that can be open or closed when it is covered by an opercular cap (see Figure 1). These galls are found in large numbers in the branches of Schinus longifolius (Lindl.) Speg. (Jörgensen 1917).

The parasitoids reported for C. eremita are the Hymenoptera Austrodolops eremitae Blanchard (Ichneumonoidea, Braconidae) (Blanchard 1936), Cecidopimpla ronnai Brèthes (Ichneumonoidea, Ichneumonidae) (Brèthes 1920), Rhynchodontomerus inclusus Jörgensen et Kieffer (Chalcidoidea, Torymidae) (De Santis \& Esquivel 1966), Eudecatoma cecidosiphaga Brèthes (Chalcidoidea, Eurytomidae) (Gates 2014), Torymus cecidicolus Brèthes (Chalcidoidea, Torymidae) and Brasema willei (Chalcidoidea, Eupelmidae) (Burks et al. 2005). Little is known about the biology and ecology of these gall-inducing species. There are no reports about the parasitoidism intensity in the natural populations or of their associated fauna (Moreira et al. 2012, Kuzmanich et al. 2015). Eucecidoses minutanus appears only in fauna catalogs, and to our knowledge, there are no reports on this species, except for a Congress communication that analyzes the morphological and genetic diversity between individuals of different sites (Brentano et al. 2012).

The aim of this communication is to report a preliminary survey of the abundance of galls produced by E. minutanus and C. eremita and the results of the examination of galls collected from different individuals of "molle" (Schinus longifolius (Lindl.) Speg.) located in an area of conserved native forest ("talar") at the Magdalena District, Buenos Aires Province, Argentina.

\section{Material and Methods}

The study was carried out in the El Destino Reserve, Magdalena District, Buenos Aires Province ( $\left.35^{\circ} 8^{\prime} \mathrm{S}, 57^{\circ} 23^{\prime} \mathrm{W}\right)$. This Reserve is located in the Pampa Deprimida, a plaine with dominant grassland and few forest. The annual mean temperature is $15^{\circ} \mathrm{C}$ and the annual mean rainfall $970 \mathrm{~mm}$.
In April 2013, the galls of C. eremita and E. minutanus were censused until two meters high in 123 randomly selected trees in a patch with conserved native forest ("talar").

The censused trees were selected through a systematic sampling with $\mathrm{k}=2$, and were marked with a code number.

For the census, the galls were classified as open (without opercular cap) or closed (with opercular cap). Additionally, in April and December 2013, E. minutanus and C. eremita galls were randomly collected and examined. The collection method consisted of three stages: first, 32 trees (16 trees in April and 16 in December) were selected using a table of random numbers; second, two branches of each tree were selected. For the selection of branches, we used a random number between 1 and 5 and selected the branches with equal number by counting the branches from the soil to the crown. Finally, we collected the first gall observed by visually inspecting the branch from the trunk to its distal end.

Collected galls were transported to the laboratory in hermetic bags, and conserved at $-18^{\circ} \mathrm{C}$ until examined. The diameter and the wall thickness were measured in each gall by means of a calliper. The wall thickness was measured after a cut at sagittal plane of the gall by a mini saw.

The inside of galls was examined with a stereoscopic microscope. The observed organisms were kept in alcohol $70 \%$ until their identification.

The data of the diameter and wall thickness in the galls of both species were tested using Shapiro Wilk test for normality (Shapiro \& Wilk 1965). Differences between the galls of both species in the diameter and wall thickness were tested using the Wilcoxon rank sum test (non-parametric data, Siegel \& Castellan 1995).

\section{Results}

Results showed that $84 \%$ of the observed "molles" (103/123) had galls of C. eremita and/or E. minutanus. No galls were observed in any of the nine saplings (lower than $1.70 \mathrm{~m}$ ) randomly selected among the 123 "molles" sampled. The percentage of closed galls per tree varied between $0 \%$ and $100 \%$ (median $=46.0 \%, \mathrm{Q} 1=26.9 \% ; \mathrm{Q} 3=62.3 \%)$. The median of closed galls per tree was $12(\mathrm{Q} 1=6 ; \mathrm{Q} 3=22)$.
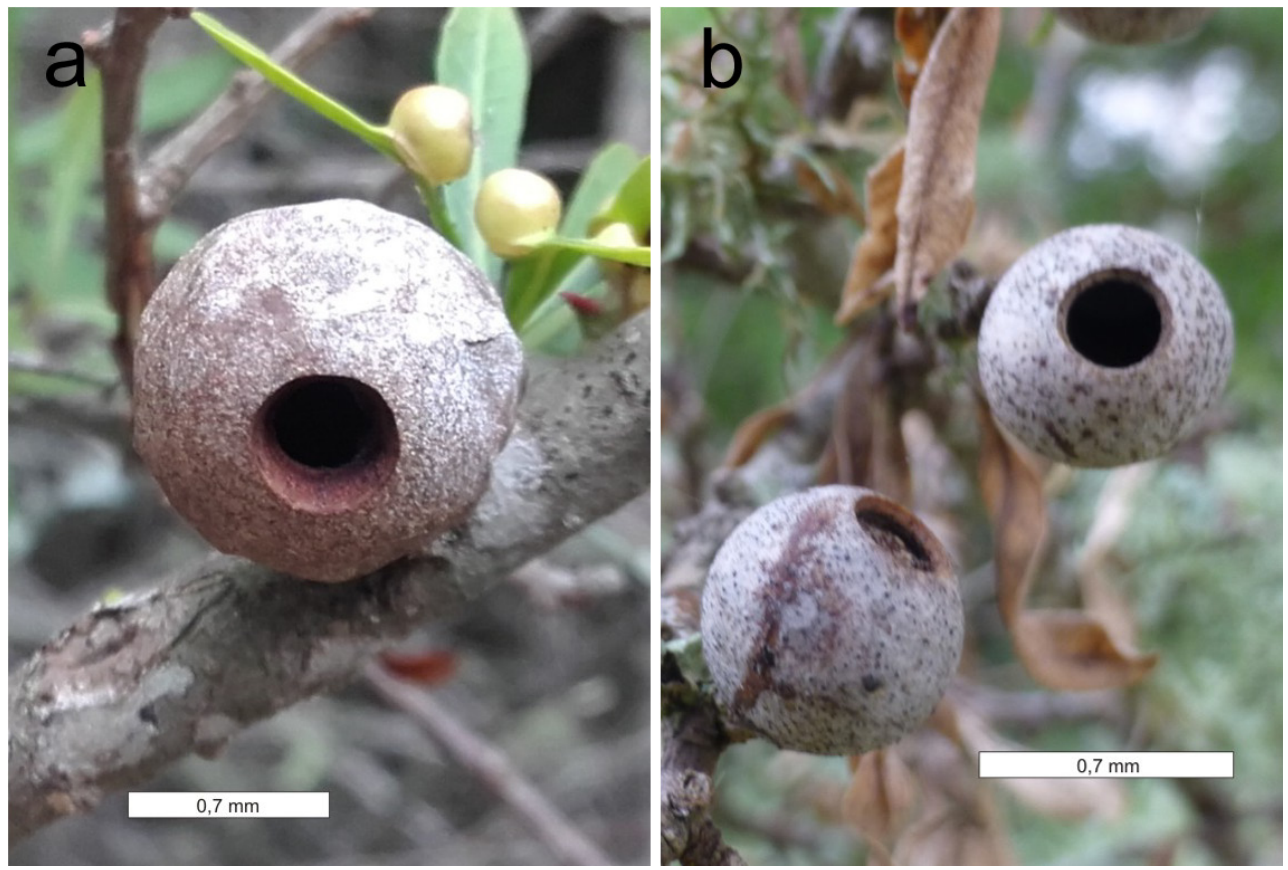

Figure 1. Galls of C. eremita (a) and E. minutanus (b) in Schinus longifolius, Magdalena, Buenos Aires. 
Table 1. Maximum diameter and wall thickness from collected galls of Eucecidoses minutanus and Cecidoses eremita, Magdalena, Buenos Aires Province, 2013.

\begin{tabular}{lccc}
\hline \multirow{2}{*}{} & \multirow{2}{*}{$\mathbf{n}$} & \multicolumn{2}{c}{ Median (first quartile-third quartile) } \\
\cline { 3 - 4 } & & Diameter $(\mathbf{c m})$ & Thickness $(\mathbf{m m})$ \\
\hline E. minutanus & 11 & $0.7(0.5-0.7)$ & $0.8(0.5-1.1)$ \\
C. eremita & 53 & $1.4(1.3-1.5)$ & $3.0(3.0-3.8)$ \\
\hline
\end{tabular}

Table 2. Number of examinated galls of Eucecidoses minutanus y Cecidoses eremita and their content, Magdalena, Buenos Aires Province, 2013.

\begin{tabular}{lcccccc}
\hline & \multicolumn{6}{c}{ Galls } \\
\cline { 2 - 3 } \cline { 5 - 7 } & \multicolumn{2}{c}{ Open } & & \multicolumn{3}{c}{ Closed } \\
\cline { 2 - 3 } \cline { 5 - 7 } & Empty & $\begin{array}{c}\text { Organisms } \\
\text { associated }\end{array}$ & & Empty & $\begin{array}{c}\text { Presence } \\
\text { of pupa }\end{array}$ & $\begin{array}{c}\text { Others } \\
\text { organisms }\end{array}$ \\
\hline E. minutanus & 6 & 2 & & 1 & 1 & 1 \\
C. eremita & 14 & 8 & & 3 & 21 & 7 \\
\hline
\end{tabular}

A total of 64 galls were collected and examined, 11 of E. minutanus and 53 of $C$. eremita. The diameter and the wall thickness were significantly different between both species. The galls of $E$. minutanus showed a lower diameter $\left(\mathrm{U}_{11 ; 53}=583.0 ; \mathrm{P}<0.05\right)$ and a lower wall thickness $\left(\mathrm{U}_{10 ; 52}=506.5\right.$; $\mathrm{P}<0.05$ ) than the galls of $C$. eremita (Table 1 ). This result did not vary when only the open galls were included $\left(\mathrm{U}_{21 ; 8}=168.0 ; \mathrm{P}<0.01\right.$ for the diameter and $\mathrm{U}_{21 ; 8}=163.0 ; \mathrm{P}<0.01$ for the thickness).

The gall numbers of each species with presence of the original pupa or other organisms are shown in Table 2. In the open galls of E. minutanus with presence of other organisms, we observed an exuvia of Pseudoescorpionida and a larva of suborder Symphyta (Hymenoptera). In the open galls of C. eremita, we found three spiders: one specimen of Ariadna boesenbergi Keyserling 1877 (Segestriidae), one specimen of the family Salticidae (Hernán Iuri, personal communication), and a group of spiders recently hatched that could not be identified. Another open gall held a Lepidoptera larva and four galls held arthropod remains that could not be identified by their degree of decomposition.

One of the three closed galls of E. minutanus held an adult of the family Torymidae (Hymenoptera) (Juan José Martínez, personal communication) and showed six little holes in its wall. Seven of the 24 closed galls of C. eremita held other organisms: three held two or three Ichneumonoidea larvae (Hymenoptera) (Juan José Martínez, personal communication), one held an adult of the family Chalcidoidea (Hymenoptera) and an unidentified larva, and the remaining galls held other insect larvae that could not be identified. All observed galls had only one chamber.

\section{Discussion}

Gall inducers show a high level of specificity to their host plants, although some plant species have different galler species (Cuevas-Reyes et al. 2003, Veldtman \& McGeoch 2003). Schinus longifolius (Lind1.) Speg. and other species of the family Anacardiaceae show several specific galler species. In a survey to identify the gall-inducing insects in the region of the Río de la Plata, $15 \%$ of all the gall morphotypes found were observed in Schinus longifolius (Lindl.) Speg., a species that would have "super host" characteristics (Veldtman \& McGeoch 2003, Kuzmanich et al. 2015). In our study area, galls of four species, including C. eremita, E. minutanus, D. congregatella (Lepidoptera: Cecidosidae), and other leaf gallers (possibly family Calophyidae (Psylloidea) (Burckhardt \& Basset 2000, Kuzmanich et al. 2015), have been observed in Schinus longifolius (Lindl.) Speg. The presence of four galler species and the high percentage of trees with galls could be due to the great abundance of this host tree in the study area (Cuevas Reyes et al. 2004).
Some authors have found an inverse relationship between the gall number and the age of host plant for several leaf gallers, and proposed that young leaves have higher nutrient value than old leaves (Washburn \& Cornell 1981, Price et al. 1987, Cuevas Reyes et al. 2004). Although our sampling included few saplings (nine), none of them showed galls of C. eremita or E. minutanus. Future studies should evaluate the potential relationship between the presence of this species and the age of the host Schinus longifolius (Lindl.) Speg.

In this preliminary study, we found that $12.9 \%$ of the closed galls of C. eremita contained some parasitoid Hymenoptera. The proportion of galls with parasitoids is very variable in space and time. Several galler-host systems have been studied by different authors. Washburn \& Cornell (1981) found that the percentages of leaf galls of the cynipid Xanthoteras politum (Bassett) with parasitoids varied between 3 and 18\%. Wool \& Burstein (1991) detected between 13-33\% of Smynthurodes betae (Aphididae) galls housing parasitoids in different sites. Almeida et al. (2006) detected $2.5 \%$ of parasitism by insect parasitoids in galls induced by Anisodiplosis waltheriae Maia (Diptera: Cecidomyiidae) while in other Cecidomyiidae Maia \& Tavares (2000) observed along 12 months parasitoidism rates between 32- 79\% in Cordiamyia globosa Maia (Diptera: Cecidomyiidae).

Other organisms were found in open galls, such as Pseudoescorpionida, also had been recorded in Cecydomidae galls (Maia 2001; Maia 2002; Rodrigues et al. 2014; Maia \& Carvalho-Fernandes 2016).

The gall abundance in host trees, the morphometric variables of galls and the proportion of galls with parasitoids are original contributions of this study because they may allow comparisons in space and time in the area and because there are no previous reports for the two species studied in the present study. In addition, the "talar" is the only native forest of Buenos Aires Province and an environment with conservation value. Thus, the study of gall-inducing species and their parasitoids or associated organisms becomes important for the design of policies on conservation of biodiversity.

\section{Acknowledgements}

We thank Fundación Elsa Shaw de Pearson for keeping the El Destino Reserve (Magdalena, Buenos Aires). Special thanks to Juan José Martínez (CONICET, Universidad de La Pampa) for the valuable contributions and comments and for showing us the galls collected by Brèthes in Museo Argentino de Ciencias Naturales. We thank Hernán Iuri for his help in the identification of spiders, Germán San Blas (CONICET, Universidad de La Pampa) for the advice regarding the conservation of galls and Osvaldo Diorio (Facultad de Ciencias Exactas y Naturales, Universidad de Buenos Aires) for providing us copies of the first papers about these moths.

\section{References}

ALBERT, S., PADHIAR, A., GANDHI, D. \& NITYANAND, P. 2011. Morphological, anatomical and biochemical studies on the foliar galls of Alstonia scholaris (Gentianales: Apocynaceae). Rev. Bras. Bot. 34(3):343-358.

ALMEIDA, F.V., SANTOS, J.C., SILVEIRA, F.A. \& FERNANDES, G.W. 2006. Distribution and frequency of galls induced by Anisodiplosis waltheriae Maia (Diptera: Cecidomyiidae) on the invasive plant Waltheria indica L. (Sterculiaceae). Neotrop. Entomol. 35(4):435-439.

ASKEW, R.R., MELIKA, G., PUJADE-VILLAR, J., SCHÖNROGGE, K., STONE, G.N. \& NIEVES-ALDREY, J.L. 2013. Catalogue of parasitoids and inquilines in cynipid oak galls in the West Palaearctic. Zootaxa. 3643:1-133.

BLANCHARD, E.E. 1936. Descripcion de Ichneumonoideos Argentinos. An. Soc. Cient. Argent. 122:398-407.

BRENTANO, A.M., GONÇALVES, G.L, SAN BLAS, G. \& MOREIRA, G.R.P. 2012. Ecological speciation and co-evolution of gall-inducing cecidosid moth 
and Schinus host plants in the Neotropics. In $58^{\circ}$ Congresso Brasileiro Do Genética. Foz do Iguaçu, p.224.

BRÈTHES, J. 1916. Estudios fitozoológicos sobre algunos lepidópteros argentinos productores de agallas. An. Soc. Cient. Argent. 82:113-140.

BRÈTHES, J. 1920. Insectos útiles y dañinos de Rio Grande do Sul y de la Plata. An. Soc. Cient. Argent. 54:281-290.

BURCKHARDT, D. \& BASSET, Y. 2000. The jumping plant-lice (Hemiptera, Psylloidea) associated with Schinus (Anacardiaceae): systematics, biogeography and host plant relationships. J. Nat. Hist. 34:57-155.

BURKS, R.A., GIBSON, G.A. \& LA SALLE, J. 2005. Nomenclatural changes in Neotropical Eulophidae, Eupelmidae and Torymidae (Hymenoptera: Chalcidoidea) relating to parasitoides of Cecidoses eremita (Lepidoptera: Cecidosidae). Zootaxa. 1082:45-55.

CUEVAS-REYES, P., QUESADA, M., HANSON, P., DIRZO, R. \& OYAMA, K. 2004. Diversity of gall-inducing insects in a Mexican tropical dry forest: the importance of plant species richness, life-forms, host plant age and plant density. J. Ecol. 92:707-716.

CUEVAS-REYES, P., SIEBE, C., MARTÍNEZ-RAMOS, M. \& OYAMA, K. 2003. Species richness of gall-forming insects in a tropical rain forest: correlations with plant diversity and soil fertility. Biodivers. Conserv. 3:411-422.

DE SANTIS, L. \& ESQUIVEL, L. 1966. Tercera lista de Himenópteros parásitos y predadores de los insectos de la República Argentina. Rev. Mus. La Plata, Secc. Zool. 9(69):47-215.

DIAS, G.G., FERREIRA, B.G., MOREIRA, G.R.P. \& ISAIAS, R.M.S. 2013. Developmental pathway from leaves to galls induced by a sap-feeding insect on Schinus polygamus (Cav.) Cabrera (Anacardiaceae). An. Acad. Bras. Cienc. 85(1):187-200.

GATES, M.W. 2014. Nomenclatural Notes on the Eurytomids (Chalcidoidea: Eurytomidae) described by Jean Brèthes housed in Museo Argentino de Ciencias Naturales "Bernardino Rivadavia”. Zootaxa. 3790:185-193.

JÖRGENSEN, P. 1917. Zoocecidios argentinos. Physis. 3:1-29.

KUZMANICH, N., ALTAMIRANO, A. \& SALVO, A. 2015. Agallas de insectos de la región Rioplatense, Buenos Aires, Argentina. Rev. Soc. Entomol. Argent. 74(1-2):47-56.

MAIA, V.C. \& TAVARES, M.T. 2000. Cordiamyia globosa Maia (Diptera, Cecidomyiidae), flutuação populacional e parasitóides (Hymenoptera) associados. Revta Bras. Zool. 17 (3): 589 - 593.

MAIA, V.C. 2001. The gall midges (Diptera, Cecidomyiidae) from three restingas of Rio de Janeiro State, Brazil. Revta Bras. Zool. 18 (2): 583 - 629.
MAIA, V.C. 2002. Description of the larva of Houardodiplosis rochae Tavares, 1925 (Diptera, Cecidomyiidae, Clinodiplosini) and new record of pseudoscorpions in galls. Rev. Bras. Entomol. 46(1): 81-82.

MAIA, V.C. \& CARVALHO-FERNANDES, S.P. 2016. Insect galls of a protected remnant of the Atlantic Forest tableland from Rio de Janeiro State (Brazil). Rev. Bras. Entomol. 60: 40-56.

MOREIRA, G.R.P., GONÇALVES, G.L., ELTZ, R.P., SAN BLAS, G. \& DAVIS D.R. 2012. Revalidation of Oliera Brèthes (Lepidoptera: Cecidosidae) based on a redescription of $O$. argentinana and DNA analysis of Neotropical cecidosids. Zootaxa. 3557:1-19.

NIEVES-ALDREY, J.L. 1998. Insectos que inducen la formación de agallas en las plantas: una fascinante interacción ecológica y evolutiva. Boln. Soc. Entomol. Aragon. 23:3-12.

PRICE, P.W., ROININEN, H. \& TAHVANAINEN, J. 1987. Plant age and attack by the bud galler, Euura mucronata (Hymenoptera: Tenthredinidae). Oecologia. 73:334-337.

PUJADE-VILLAR, J. \& ROS-FARRÉ, P. 1998. Inquilinos y parasitoides de las agallas del Género Plagiotrochus Mayr (Hymenoptera: Cynipidae) colectadas en el nordeste de la Península Ibérica. Boln. Asoc. esp. Ent. 22(1-2):115-143.

RODRIGUES, A.R., MAIA, V.C. \& MÁRCIA SOUTO COURI, M. 2014. Insect galls of restinga areas of Ilha da Marambaia, Rio de Janeiro, Brazil. Rev. Bras. Entomol. 58(2): 173-197.

SHAPIRO, S.S. \& WILK, M.B. 1965. An analysis of variance test for normality (complete samples). Biometrika. 52(3-4):591-611.

SIEGEL, S. \& CASTELLAN, N.J. 1995. Estadística no paramétrica aplicada a las ciencias de la conducta. Ediciones Trillas, México.

STONE, G.N. \& SCHÖNROGGE, K. 2003. The adaptive significance of insect gall morphology. Trends. Ecol. Evol. 18(10):512-522.

VELDTMAN, R. \& MCGEOCH, M.A. 2003. Gall-forming insect species richness along a non-scleromorphic vegetation rainfall gradient in South Africa: the importance of plant community composition. Austral Ecol. 28:1-13.

WOOL, D. \& BURSTEIN, M. 1991. Parasitoids of the gall-forming aphid Smynthurodes betae [Aphidoidea: Fordinae] in Israel. Entomophaga. 36(4):531-538.

WASHBURN, J.O. \& CORNELL, H.V. 1981. Parasitoids, patches, and phenology: their possible role in the local extinction of a cynipid gall wasp population. Ecology. 62:1597-1607. 